\title{
GAS CHROMATOGRAPHY-MASS SPECTROMETRY ANALYSIS OF VIBURNUM OPULUS (L) EXTRACT AND ITS TOXICITY STUDIES IN RATS
}

\author{
ABIODUN HUMPHREY ADEBAYO*, ARISTOTLE B ALADE, OMOLARA FAITH YAKUBU
}

Biochemistry and Molecular Biochemistry Unit, Department of Biological Sciences, College of Science and Technology, Covenant University, PMB 1023, Canaan Land, Ota, Ogun State, Nigeria. Email: abiodun.adebayo@covenantuniversity.edu.ng

Received: 29 January 2017, Revised and Accepted: 18 March 2017

\section{ABSTRACT}

Objectives: This study was aimed at establishing the antimicrobial and phytochemical profiles of Viburnum opulus (L) as well as the safety potential of the extract in albino Wistar rats.

Methods: Ethanol, n-hexane, ethyl acetate, butanol, and water fractions were prepared for both phytochemical assessments using gas chromatographymass spectrometry analysis (GC-MS). Five groups of seven rats were used for the study. Group A received distilled water (control), while Groups B to E were treated, respectively, with 250,500,1000, and $1500 \mathrm{mg} / \mathrm{kg}$ body weight of $V$. opulus extract by abdominal canalization for 28 days. Blood samples were obtained for biochemical analyses, and the liver tissues were further processed for histological studies.

Results: The GC-MS spectra revealed the existence of various phytoconstituents such as neophytadiene, germaciene, and caryophyllene among others. High-density lipoprotein and albumin were significantly $(\mathrm{p}<0.05)$ elevated in animals administered with 500,1000 , and $1500 \mathrm{mg} / \mathrm{kg}$ bw of the leaf extract. Ethanol, butanol, and water fractions of the leaf of $V$. opulus showed antimicrobial action against most of the organisms used in this study.

Conclusion: The result indicates that $V$. opulus leaf extract contains a wild range of fatty acids and heterocyclic compounds with antimicrobial efficacy and showing no hepatic damage.

Keywords: Viburnum opulus, Gas chromatography-mass spectrometry analysis, Biochemical, Antimicrobial, Histology.

(C) 2017 The Authors. Published by Innovare Academic Sciences Pvt Ltd. This is an open access article under the CC BY license (http://creativecommons. org/licenses/by/4. 0/) DOI: http://dx.doi.org/10.22159/ajpcr.2017.v10i6.17350

\section{INTRODUCTION}

Viburnum genus belonging to the Caprifoliaceae family, consist of about 230 species all across the Southeast Asia and South America [1]. It constitutes four different species in the native of Turkey; which includes Viburnum lantana L., Viburnum orientale Pallas, Viburnum tinus L., and Viburnum opulus L. [2]. The genus has medicinal uses ranging from antispasmodic, diuretic, hepatoprotective, antiinflammatory, and antisedative effects [3,4]. A local drink called "gilaburu" was formulated from the fruit of V. opulus in Middle Anatolia while the bark of $V$. lantana is known for its analgesic potential [5]. The antioxidative property of $V$. dilatatum was observed in rats exposed to stress [6] and in diabetic rats [7]. The genus Viburnum has been reported to contain a vast array of phytochemicals such as diterpenoids $[8,9]$, triterpenoids [10,11], iridoids [12], sesquiterpenes [13], and polyphenols [1]. The various biochemical activities of the plant genus are probably associated with the phytochemicals it contains. Out of all the secondary metabolites reported to be contained in the genus Viburnum, the polyphenols have gained much awareness in recent years owing to the fact that they display a vast array of biological activities which includes antibacterial, antioxidant, antimicrobial, anti-inflammatory, and anti-thrombotic properties [14]. This study is on $V$. opulus (L.) which is also known as snowball tree or the guilder rose [15]. The antioxidant activity of $V$. opulus has been reported [16]. This study will be the first where in the bioactive compounds of $V$. opulus are ascertained via gas chromatography-mass spectrometry (GC-MS) technique; moreover, no literature has also document its toxicity evaluation in albino Wistar rats. It is, therefore, imperative to access the sub-acute toxicity of the leaf extract of $V$. opulus in rats and furthermore determine its phytochemical and antimicrobial profiles in different solvent fractions.

\section{METHODS}

\section{Plant materials}

Fresh green leaves of $V$. opulus (Egungun eja) were obtained from Benja Community, Ado-Odo Ota, Local Government Area, Ogun State, Nigeria. The plant was authenticated by a taxonomist, Dr. A. C. Omonhinmin in Biological Sciences Department, Covenant University.

\section{Extract preparation}

The fresh leaves were allowed to dry for 2 weeks under room temperature and subsequently pulverized to powder form. $666 \mathrm{~g}$ of the pulverized leaves were soaked in $90 \%$ ethanol for $72 \mathrm{hrs}$, and a $10 \%$ yield of the ethanolic extract was obtained at reduced pressure of $50^{\circ} \mathrm{C}$ with the aid of a rotary evaporator. The crude ethanolic extract was thereafter subjected to sequential fractionation using hexane, ethyl acetate, and butanol, respectively, to obtain hexane, ethyl acetate, butanol, and water fractions [17]. The different fractions were used for the GC-MS analysis.

\section{Phytochemical analysis}

Different fractions of $V$. opulus leaves were exposed to phytochemical analysis to detect the existence of any of the following; saponins, alkaloids, proteins, carbohydrates, coumarin, amino acids, anthraquinone glycosides, tannin, flavonoids, phenolic compounds terpenes, quinone, and using standard procedures [18].

\section{GC-MS analysis}

This was performed using a GC (Hewlett Packard; model 6890 series) having an ionization flame detector, injector with a temperature of $250^{\circ} \mathrm{C}$. Temperature was set at $50^{\circ} \mathrm{C}$ for 5 minutes and further increased at a steady rate of $2^{\circ} \mathrm{C} /$ minutes. The gas used was $99.9 \%$ helium gas after which $1 \mu \mathrm{m}$ of the extract was injected at a ratio of 1 to 30 (1:30). 
The GC (Model 6890 series) was equipped with NIST14.L Library software database.

\section{Antimicrobial activity}

Antimicrobial activity of the different fractions was performed using agar well diffusion method and this was tested against Escherichia coli, Staphylococcus aureus, Proteus vulgaris, Pseudomonas aeruginosa, Bacillus spp., and Micrococcus spp. Bacterial culture (16 hrs old) was swabbed on the prepared Muller-Hinton agar (Hi Media, India) plates and left to dry for about 5 minutes. Using a sterile cork borer, 4 wells $5 \mathrm{~mm}$ in diameter was drilled on the plates. A total concentration of $30 \mathrm{mg} / \mathrm{ml}$ of extract was prepared by dissolving in their appropriate solvents. Varying concentrations of the extract $(300,600,900$, and $1200 \mu \mathrm{g}$ ) were stacked onto the wells, allowing it to circulate for about 10 minutes. These were further incubated at $37^{\circ} \mathrm{C}$ for $24 \mathrm{hrs}$. The width of inhibition zone was estimated and recorded after incubation.

\section{Experimental animals}

A total of 35 healthy male albino Wistar rats with weight ranging from 82 to $190 \mathrm{~g}$, were obtained at the Animal breeding centre, Federal University of Technology, Abeokuta, Ogun State, Nigeria. The rats were kept in a well-aerated room with standard conditions $\left(12 / 12 \mathrm{hrs}\right.$ light $/$ dark cycle, $25^{\circ} \mathrm{C}$ and $65 \%$ humidity), and fed with quality rat chow including water (Graceline feeds, Ota, Ogun state). The animals were left to adjust to the environment for 2 weeks during which they were been assessed for morphological/behavioral changes before the inception of the experiment. The animals were handled following the recommendations for the use and care of laboratory animals stated by the National Institutes of Health [19].

\section{Sub-chronic toxicity studies}

The method according to Adebayo et al. [20] was adopted. Thirty-five (35) male albino Wistar rats were divided into five groups containing seven rats per group.. The control (Group A) was administered $1 \mathrm{ml}$ of distilled water. Groups B to E orally received varying concentrations $(250,500,1000$, and $1500 \mathrm{mg} / \mathrm{kg}$ body weight) of the extract for 28 days. At the close of the administration, food was withdrawn from the animals overnight and anesthetized in diethyl ether and subsequently dissected and blood samples obtained from the heart into lithium heparin and ethylenediaminetetraacetic acid bottles. The samples collected in the lithium heparin bottles were centrifuged at $3000 \times \mathrm{g}$ for 10 minutes to obtain the plasma, which was further preserved in $-20^{\circ} \mathrm{C}$ until required for the various analysis. The organ (liver) was obtained for histological assessment. The experimental procedure was approved by the ethics committee of the Department of Biological Sciences, Covenant University, Nigeria.

\section{Biochemical parameters determination}

Biochemical parameters such as alkaline phosphatase [21], aspartate aminotransferase (AST) [22], alanine aminotransferase (ALT) [23], total bilirubin [24], albumin [25], urea [26], low-density lipoprotein (LDL) [27], high-density lipoprotein (HDL), and cholesterol [28] were assayed by using an auto-analyzer (Archem BM240, Turkey).

\section{Statistical analysis}

Data were expressed as mean \pm standard error of mean and analyzed with one-way ANOVA along with Tukey's post-hoc using the Statistical Package for Social Sciences (SPSS) (SPSS Inc., Chicago, IL, USA). p $<0.05$ was considered statistically significant.

\section{RESULTS}

Result obtained from the phytochemical analysis is as shown in Table 1. The hexane fraction showed the existence of saponins, glycosides, steroids, tannins, quinines, and phenols while the ethyl acetate fraction showed the presence of alkaloid, phenol, coumarin, and steroids. The butanol fraction revealed the presence of tannin, saponin, alkaloid, terpenoids, and phenols.

The ethanolic extract, butanol, and water fraction of $V$. opulus showed some level of inhibitory activity against most of the microorganism tested (Table 2). The organisms were, however, resistant to the N-hexane and ethyl acetate fraction. The diameter of the zone of inhibition varied from 4 to $9 \mathrm{~mm}$.

GC-MS analysis of ethanol, butanol, hexane, and water fractions are shown in Fig. 1a-d. This revealed different peaks. GC-MS analysis of the butanol fraction revealed 34 bioactive compounds (Fig. 1c). First compound identified with less retention time (RT) (7.40 minutes) in the butanol extract was butane 1,1 , dibutoxy $(1.01 \%)$ while the prominent compound was diethyl phthalate having 26 different but very close RTs.

The water fraction showed 29 bioactive compounds (Fig. 1d). The predominant compound was phytol with RT of 23.84 minutes while

Table 1: Phytochemical analysis of fractions of V. opulus leaves

\begin{tabular}{|c|c|c|c|c|c|}
\hline S.No. & Phytochemicals & Ethanolic extract & $\mathrm{N}$-hexane extract & Ethyl acetate extract & Butanol extract \\
\hline 1 & Carbohydrate & - & - & + & - \\
\hline 2 & Tannin & + & + & - & + \\
\hline 3 & Saponin & - & + & - & + \\
\hline 4 & Alkaloid & + & - & + & + \\
\hline 5 & Flavanoids & + & - & - & - \\
\hline 6 & Quinones & - & + & - & - \\
\hline 7 & Glycoside & - & + & - & - \\
\hline 9 & Terpenoids & + & - & - & + \\
\hline 10 & Phenol & - & + & + & + \\
\hline 11 & Coumarin & + & - & + & - \\
\hline 12 & Steroids & + & + & + & - \\
\hline
\end{tabular}

+: Positive, -: Negative, V. opulus: Viburnum opulus

Table 2: Zone of inhibition of fractions of $V$. opulus against some bacteria

\begin{tabular}{lllll}
\hline Organism & EF (mm) & NF (mm) & EAF (mm) & BF (mm) \\
\hline Escherichia coli & 8 & - & - & 7 \\
Staphylococcus aureus & 7 & - & - & 9 \\
Proteus vulgaris & 8 & - & - & 6 \\
Pseudomonas aeruginosa & 6 & - & - & 6 \\
Bacillus spp. & 8 & - & - & - \\
Micrococcus spp. & 4 & - & - & 6 \\
\hline
\end{tabular}

EF: Ethanolic fraction, NF: N-hexane fraction, EAF: Ethyl acetate fraction, BF: Butanol fraction, WF: Water fraction, V. opulus: Viburnum opulus 


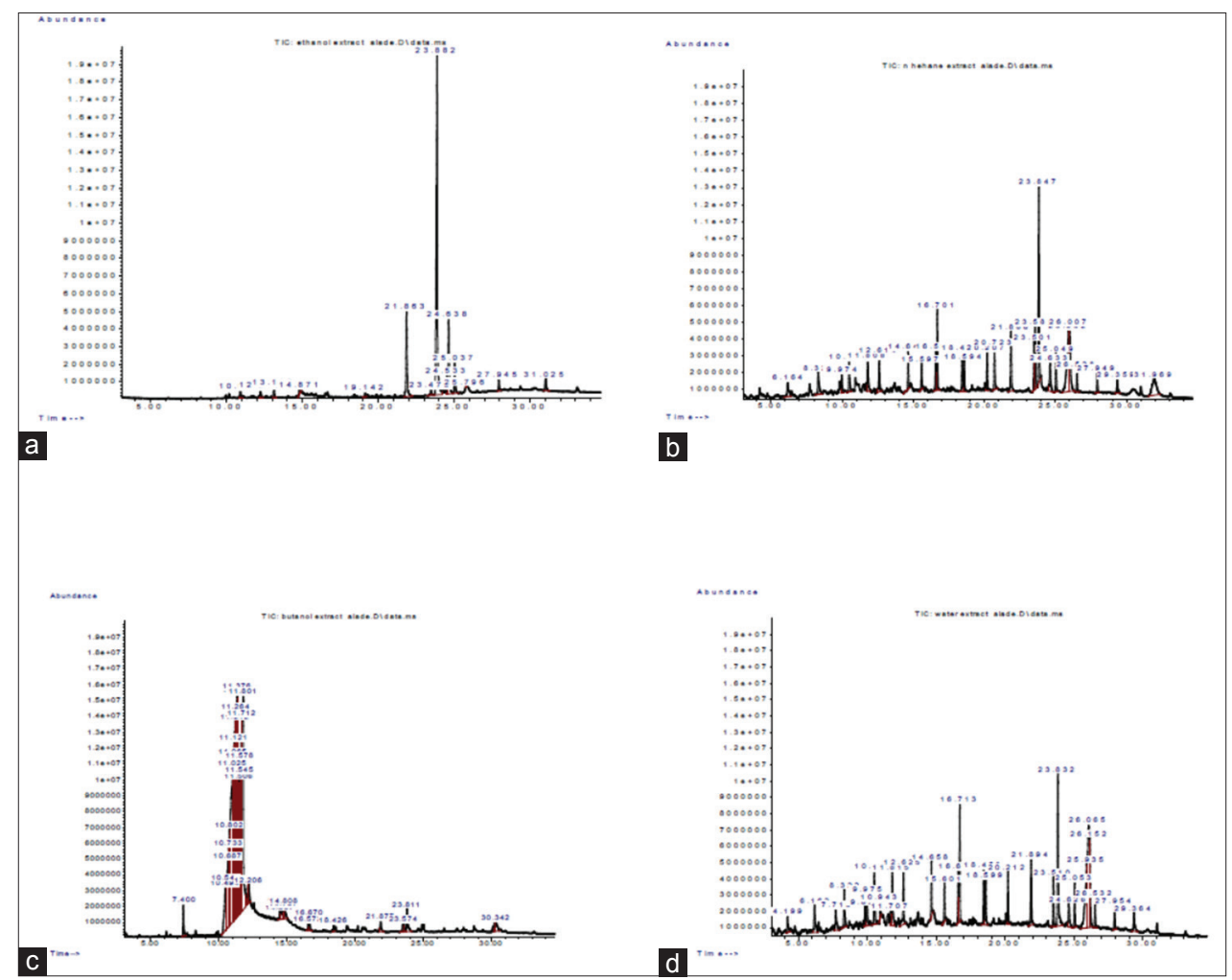

Fig. 1: The gas chromatography-mass spectrometry chromatogram of fractions of Viburnum opulus, (a) ethanolic extract, (b) hexane, (c) butanol, (d) water fraction

other prevalent compounds present were pentadecane 2,6,10,14 tetramethyl (6.22\%), squalene (13.15\% and 5.47\%) (Fig. 1b).

The hexane fraction revealed 27 compounds; the first compound with the least RT (6.16 minutes) was heptane, 2,6-dimethyl-oxalic acid, and isobutyl nonyl ester $(2.12 \%)$ while the prominent one was phytol (15.37\%) having RT of 23.84 minutes.

Finally, from the ethanol crude extract, 14 different compounds were identified via the GC-MS. The major one was phytol (58.55\%) which was also present in other fractions (Fig. 1a). Table 3 shows the RT along with the structures of the phytochemical constituents identified by GCMS spectra in the ethanolic extract of $V$. opulus.

\section{Biochemical analysis}

The result of the toxicity study showed no significant elevation in ALT and AST level $(\mathrm{p}<0.05)$ (Fig. 2a and b) in all treated groups. The ethanolic extract of $V$. opulus significantly increased the HDL level in the serum ( $p<0.05$ ) (Fig. 3b) while no significant change in the serum LDL level was observed (Fig. 3a). There was a reduction in the serum triglyceride level but not significant (Fig. 3c). Furthermore, there was a dose-dependent significant increase in serum albumin levels in the 500, 1000 , and $1500 \mathrm{mg} / \mathrm{kg}$ groups (Fig. 2d) while the reduction observed in the urea levels in all treated groups was not significant (Fig. 2e).

\section{Histopathological studies}

No cellular nor fibrotic damage of rats' liver tissues was detected across all treatment groups in comparison with the control group (Fig. 4a-e).

\section{DISCUSSION}

V. opulus L. is cultivated as an ornamental plant in different countries, and the dried fruits have been reported to contain organic acids and phenolic glucoside which were used to treat uterine cramps and used as general pain killer [29]. The biological activities of medicinal plants are associated with the type and nature of secondary plant metabolites they contain. The phytochemical investigation which showed the presence of tannins, saponins, phenols, flavonoids, terpenoids, and steroids (Table 1) is in line with the previous studies as reported by Yilmaz et al. [4]. From the antimicrobial screening (Table 2), the butanol fraction was the most effective against the entire microorganism tested having a zone of inhibition ranging from 6 to $9 \mathrm{~mm}$ as compared with other fraction with no activity. The presence of saponin might be responsible for it antimicrobial effect as saponin has been reported to have an inhibitory effect on Gram-positive bacteria [30]. It is interesting to note that the butanol fraction was active against $S$. aureus, an infectious agent associated with several animal and human infections. Furthermore, the saponins from the ethanolic crude extract are complementary to standard antibiotics like the penicillin used in this study.

The GC-MS analyses, as shown in Fig. 1c of the butanol fraction identified some phytochemical compounds such as octadecane $(0.19 \%)$, hexadecane $(0.46 \%)$, heneicosane $(0.24 \%)$, 9-octadecenoic acid(Z)-, methyl (0.41\%), phytol (1.15\%), phthalic acid, monooctyl ester $(0.49 \%)$, and $1 \mathrm{H}$-Indole, 5 -methyl-2-phenyl- $(0.60 \%)$ with the longest RT of 30.34. Phytol which is one of the compounds identified in the butanol fraction; is an essential component of plants that is used in making toilet soaps, shampoo, and general household cleaners as a result of its high antimicrobial against food borne pathogens [31] and also a precursor in manufacturing synthetic forms of vitamin $\mathrm{K}$ and vitamin E [32,33]. Inoue et al. [34] reported phytol to have antibacterial activity against $S$. aureus by causing cell membrane damage; this is in line with this study where the butanol fraction was found to be active against $S$. aureus. The water fraction contains bioactive such as oxalic acid, allyl tridecyl ester (1.27\%), heptane, 2,6-dimethyl- dodecane (2.59\%), octane, 3,6-dimethyl-(1.81\%), tridecane (2.79\%), decahydro-1,1,4a,5,6-pentamethylnaphthalene $(1.39 \%)$, dodecane, $2,6,10$-trimethyl- $(1.6 \%)$, tetradecane $(3.34 \%)$, and 2-pentanone, 4-cyclohexylidene-3,3 -diethyl- (0.67\%). The hexane fraction analyzed by GC-MS identified compounds such as tridecane $(2.77 \%)$, dodecane, 2,6,10-trimethyl $(1.55 \%)$, tetradecane $(2.73 \%), 2,6,10$-trimethyldecane $(2.89 \%)$, pentadecane $(2.92 \%)$, 


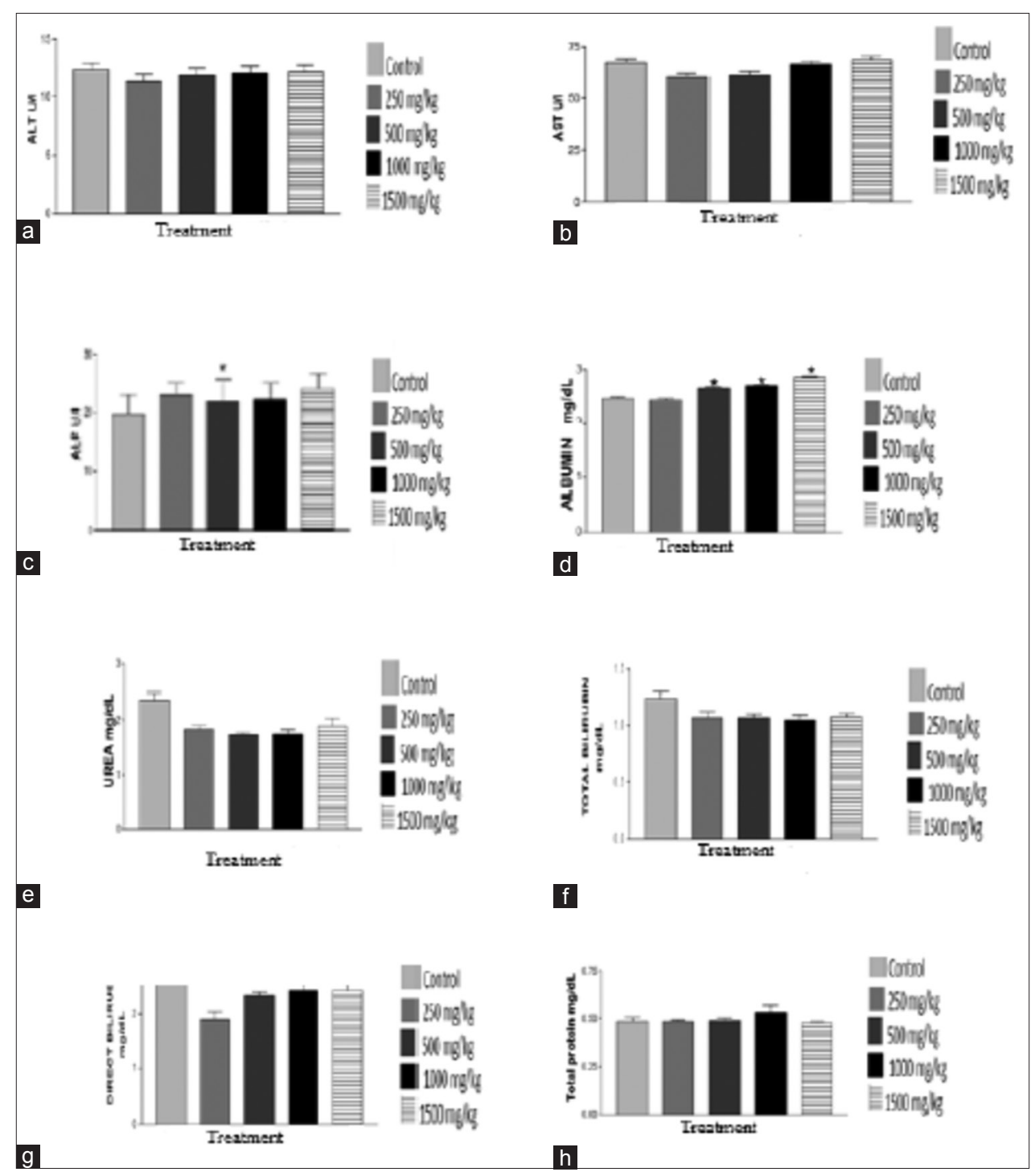

Fig. 2: Effect of Viburnum opulus extract on liver function parameters in albino Wistar rats after 28-day treatment, (a) Alanine aminotransferase, (b) aspartate aminotransferase, (c) alkaline phosphatase, (d) albumin, (e) urea, (f) total bilirubin, (g) direct bilirubin, (h) total protein. Values presented as mean \pm standard error of mean of 7 replicates. $\mathbf{p}<0.05$ are accounted as statistically significant in comparison with the control group

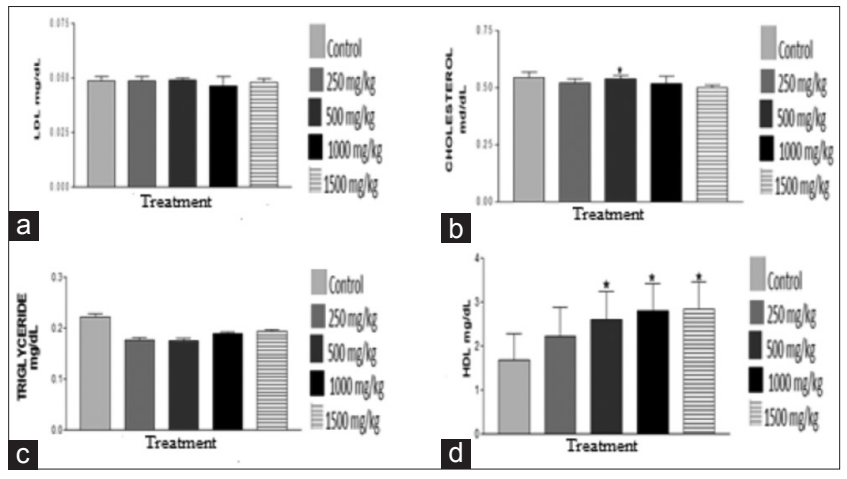

Fig. 3: The outcome of Viburnum opulus extract on the lipid profile of albino Wistar rats, (a) Low-density lipoprotein, (b) total cholesterol, (c) triglyceride, (d) high-density lipoprotein. Values represent mean \pm standard error of mean of 7 replicates. ${ }^{*} p<0.05$ are accounted as statistically significant in comparison with the control group hexadecane (2.27\%), tridecane, 5-propyl (1.6\%), heptadecane (2.64\%), pentadecane, 2,6,10,14-tetramethyl (5.54\%), octadecane (2.64\%), hexadecane,2,6,10,14-tetramethyl (2.24\%), nonadecane $(2.50 \%)$, hexadecanoic acid, methyl ester (3.32\%), hexadecanoic acid, ethyl ester (5.21\%), heneicosane (3.06\%), 9--octadecenoic acid, methyl ester (4.30\%), phytol (15.37\%), ethyl 9,12,15-octadecatrienoate (2.85\%), eicosane $(2.71 \%)$, squalene $(9.31,2.54,6.57 \%)$, tricosane $(1.45 \%)$, tetracosane $(1.34 \%)$, docosane $(1.33 \%)$, and alpha-tocopherol (6.17\%). Hexadecanoic acid identified in the hexane fraction has been reported to have antibacterial, antioxidant, and antitumor properties [35].

Furthermore, the ethanolic extract revealed the presence of caryophyllene $(0.99 \%$; the first compound with the least RT of 10.9 minutes) as shown in Table 3. The previous studies have reported $\alpha$-caryophyllene and $\beta$-caryophyllene as anticancer essential oil components [36]. Park et al. [37] also reported the anti-tumorigenic potential of caryophyllene where he identified the down-regulation of vascular endothelial growth factor as the mechanism of action of caryophyllene. Phytol; the prominent compound identified in the water, hexane and crude extract has been reported to demonstrate 
Table 3: Phytochemical components of the ethanolic leaf extract of V. opulus (L.) as revealed by GC-MS spectra

\begin{tabular}{|c|c|c|c|c|}
\hline S.No. & Compound name & Area percentage & RT (minutes) & Structure \\
\hline 1 & Caryophyllene & 0.99 & 10.914 & \\
\hline 2 & 1,2,3,5,6,8a-hexahydro-4,7-dimethyl-1(1-methylethyl)-(1S-cis) & 1.37 & 13.129 & \\
\hline 3 & Germaciene D & 1.20 & 12.242 & \\
\hline 4 & Diethyl phthalate & 0.17 & 14.868 & \\
\hline 5 & Neophytadiene & 0.53 & 19.143 & \\
\hline 6 & Hexadecanoic acid, ethyl ester & 2.18 & 31.027 & \\
\hline 7 & Ethyl 14-methyl-hexadecanoate & 0.61 & 23.474 & \\
\hline 8 & Phytol & 58.55 & 23.880 & \\
\hline 9 & Linoleic acid ethyl ester & 2.02 & 24.533 & \\
\hline 10 & 9,12,15-octadecatrienoic acid, ethyl ester (Z, Z, Z) & 12.62 & 24.636 & \\
\hline 11 & Octadecanoic acid ethyl ester & 4.65 & 25.036 & \\
\hline 12 & Squalene & 0.02 & 25.797 & \\
\hline 13 & Eicosanoic acid ethyl ester & 1.42 & 27.943 & \\
\hline 14 & Docosanoic acid ethyl ester & 2.18 & 31.027 & \\
\hline
\end{tabular}

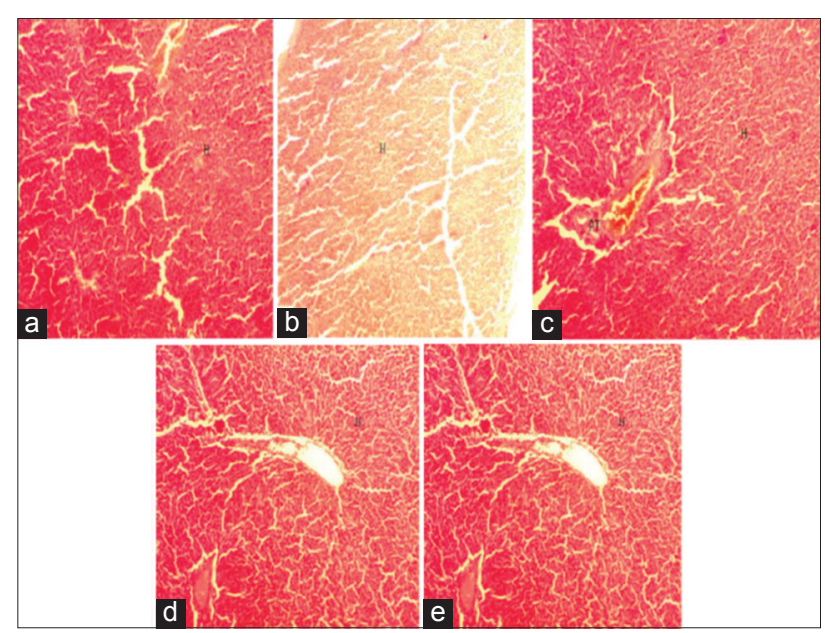

Fig. 4: Microphotograph of liver tissues of rats treated with Viburnum opulus extract showing hepatocyte $(\mathrm{H})$ and portal vein (PV) (magnification $\times 200$ ): (a) Control, (b) $250 \mathrm{mg} / \mathrm{kg}$ (c) $500 \mathrm{mg} / \mathrm{kg}$, (d) $1000 \mathrm{mg} / \mathrm{kg}$, (e) $1500 \mathrm{mg} / \mathrm{kg}$ bw

antioxidant effect [38]. The ethanolic extract of $V$. opulus did not create any gross toxicological indications or death. Urea is used as a marker for kidney toxicity; as the glomerular damage is indicated by increased blood urea level which is often metabolized by the liver in urea cycle. However, there was no significant alteration in the urea level (Fig. 2e). No variation in the serum urea level which indicates the proper functioning of the kidneys. It is well known that liver damage is normally determined by the level of serum transaminases especially
ALT. Certainly, non alteration in the serum ALT, AST, bilirubin, and protein is indicative of a lack of liver dysfunction and/or damage. These results were furthermore confirmed by the histological studies on the liver tissues where no degeneration of the liver tissues was observed (Fig. 4). The increase in albumin levels seen in the 500, 1000, and $1500 \mathrm{mg} / \mathrm{kg}$ bw groups may constitute a high risk of colloid osmotic blood pressure at increased doses of the plant extract. However, since albumin is important in determining the stability of the glomerular membrane and assessing the extremity of the disease associated with it [39], elevated levels observed in the treated groups may indicate improvement or increase in the liver function as increased albumin is essentially due to high liver synthetic ability [40]. HDL levels were significantly elevated $(\mathrm{p}<0.05)$ however reduction in LDL-cholesterol and triglyceride levels were observed. This indicates that the extract may have some potential effect to minimize cardiovascular risk factors which can otherwise lead to death [41]. Therefore, the extract of $V$. opulus is relatively harmless while the presence of various bio-active compounds detected after GC-MS analysis using the ethanolic extract of $V$. opulus accounts for the various uses by the traditional practitioner.

\section{CONCLUSION}

The GC-MS analysis suggests that the ethanolic leaf extract of $V$. opulus contains a wild range of fatty acids, heterocyclic compound with diverse antimicrobial properties and it is not toxic to rats within the dosage limit investigated.

\section{REFERENCES}

1. Lobstein A, Weniger B, Malecot V, Um BH, Alzate F, Anton R. Polyphenolic content of two Colombian Viburnum species (Caprifoliaceae). Biochem Syst Ecol 2003;31:95-7. 
2. Davis PH, Mill RR, Tan K. Flora of Turkey and the East Aegean Islands. Vol. 10. Edinburgh: Edinburgh University Press; 1988. p. 154

3. Cometa MF, Nazzanti G, Tomassini L. Sedative and spasmolytic effects of Viburnum tinus L. and its major pure compounds. Phytother Res 1998;12:89-91. Available from: https://www.eurekamag.com/pdf. php?pdf $=003267340$.

4. Yilmaz BS, Citoglu GS, Altun ML, Ozbek H. Antinociceptive and anti-inflammatory activities of Viburnum lantana. Pharm Biol 2007;45(3):241-5. Available from: http://www.tandfonline.com/doi/ pdf $/ 10.1080 / 13880200701213187$ ?needAccess $=$ true.

5. Baytop T. Therapy with Medicinal Plants in Turkey. $2^{\text {nd }}$ ed. Istanbul: Nobel Tip Kitabevleri; 1999. p. 210.

6. Iwai $\mathrm{K}$, Onodera A, Matsue $\mathrm{H}$. Antioxidant activity and inhibitory effect of Gamazumi (Viburnum dilatatum THUNB.) on oxidative damage induced by water immersion restraint stress in rats. Int J Food Sci Nutr 2001;52(5):443-51.

7. Iwai K, Onodera A, Matsue H. Inhibitory effects of Viburnum dilatatum Thunb. (gamazumi) on oxidation and hyperglycemia in rats with streptozotocin-induced diabetes. J Agric Food Chem 2004:52(4):1002-7.

8. Fukuyama Y, Kubo M, Minami H, Yuasa H, Matsuo A, Fujii T, et al. Rearranged vibsane-type diterpenes from Viburnum awabuki and photochemical reaction of vibsanin B. Chem Pharm Bull (Tokyo) 2005;53(1):72-80

9. Kubo M, Chen IS, Fukuyama Y. Vibsane-type diterpenes from Taiwanese Viburnum odoratissimum. Chem Pharm Bull (Tokyo) 2001;49(2):242-5.

10. Fukuyama Y, Minami H, Fujii H, Tajima M. Triterpenoids from Viburnum suspensum. Phytochemistry 2002;60(8):765-8.

11. Kagawa M, Minami H, Nakahara M, Takahashi H, Takaoka S, Fukuyama Y. Oleanane-type triterpenes from Viburnum awabuki. Phytochemistry 1998;47(6):1337-41.

12. Tomassini L, Foddai S, Nicoletti M, Cometa MF, Palazzino G, Galeffi C. Iridoid glucosides from Viburnum ayavacense. Phytochemistry 1997;46(5):901-5

13. Fukuyama Y, Minami H, Ichikawa R, Takeuchi K, Kodama M. Hydroperoxylated guaiane-type sesquiterpenes from Viburnum awabuki. Phytochemistry 1996;42:741-6.

14. Santos SA, Vilela C, Freire CS, Neto CP, Silvestre AJ. Ultra-high performance liquid chromatography coupled to mass spectrometry applied to the identification of valuable phenolic compounds from Eucalyptus wood. J Chromatogr B Analyt Technol Biomed Life Sci 2013;938:65-74.

15. Zayachkivska OS, Gzhegotsky MR, Terletska OI, Lutsyk DA, Yaschenko AM, Dzhura OR. Influence of Viburnum opulus proanthocyanidins on stress-induced gastrointestinal mucosal damage. J Physiol Pharmacol 2006;57 Suppl 5:155-67.

16. Iwai K, Kim MY, Onodera A, Matsue H. Alpha-glucosidase inhibitory and antihyperglycemic effects of polyphenols in the fruit of Viburnum dilatatum Thunb. J Agric Food Chem 2006;54(13):4588-92.

17. Adebayo AH, Aliyu R, Gatsing D, Garba IH. The effects of ethanolic leaf extract of Commiphora africana (Burseraceae) on lipid profile in rats. Int J Pharmacol 2006;2:618-22. Available from: http://www. scialert.net/abstract/?doi=ijp.2006.618.622.

18. Harborne JB. Phytochemical Methods: A Guide to Modern Techniques of Plant Analysis. London: Chapman and Hall; 1973.

19. National Institute of Health (NIH). Guide for the Care and Use of Laboratory Animals. USA: NIH Publication; 1985. p. 85-123.

20. Adebayo AH, Abolaji AO, Opata TK, Adegbenro IK. Efects of ethanolic leaf extract of Chrysophyllum albidum G. on biochemical and haematological parameters of albino Wistar rats. Afr J Biotechnol 2010;9(14):2145-50. Available from: http://www.academicjournals. org/journal/AJB/article-abstract/2AB347320356.

21. Tietz NW, Rinker AD, Shaw LM. IFCC methods for the measurement of catalytic concentration of enzymes part 5. IFCC method for alkaline phosphatase (orthophosphoric-monoester phosphohydrolase, alkaline optimum, EC 3.1.3.1). J Clin Chem Clin Biochem 1983;21(11):731-48.

22. Bergmeyer HU, Herder M, Rej R. International Federation of Clinical Chemistry (IFCC) scientific Committee, analytical section: Approved recommendation (1985) on IFCC methods for the measurement of catalytic concentration of enzymes. Part 2. IFCC method for aspartate aminotransferase (L-aspartate: 2-oxoglutarate aminotransferase, EC 2.6.1:1.). J Clin Chem Clin Biochem 1986a;24(7):497-510.

23. Bergmeyer HU, Hørder M, Rej R. International Federation of Clinical Chemistry (IFCC) scientific Committee, analytical section: Approved recommendation (1985) on IFCC methods for the measurement of catalytic concentration of enzymes. Part 3. IFCC method for alanine aminotransferase (L-alanine: 2-oxoglutarate aminotransferase, EC 2.6.1:2.). J Clin Chem Clin Biochem 1986b;24(7):481-95.

24. Doumas BT, Perry BW, Sasse EA, Straumfjord Jr JV. Standardization in bilirubin assays: Evaluation of selected methods and stability of bilirubin solutions. Clin Chem 1973;19(9):984-93. Available from: http://www.clinchem.aaccjnls.org/content/clinchem/19/9/984.full.pdf.

25. Doumas BT, Watson WA, Biggs HG. Albumin standards and the measurement of serum albumin with bromcresol green. Clin Chim Acta 1971;31(1):87-96

26. Krieg M, Gunsser KJ, Steinhagen-Thiessen E, Becker H. Comparative quantitative clinico-chemical analysis of the characteristics of 24-hour urine and morning urine. J Clin Chem Clin Biochem 1986;24(11):863-9.

27. Bartels $\mathrm{H}$, Bohmer M. A colorimetric method for determination of serum creatinine. J Clin Chem Acta 1972:37:193.

28. Abel LL, Levy BB, Brodie BB, Kendall FE. A simplified method for the estimation of total cholesterol in serum and demonstration of its specificity. J Biol Chem 1952;195(1):357-66.

29. Prajapati ND, Purohit SS, Sharma AK, Kumar A. A Handbook of Medical Plants. India: Agrobios; 2003.

30. Soetan KO. Evaluation of Some Pharmaceutical and Haematological Activities of Saponins in Guinea Corn (Sorghum bicolor L. Moench). Ibadan: M.Sc Dissertation, Department of Biochemistry, College of Medicine, University of Ibadan; 2003.

31. Sermakkani M, Thangapandian V. GC-MS analysis of Cassia italica leaf methanol extracts. Asian J Pharm Clin Res 2012;5(2):90-4.

32. Ruby K, Chauhan R, Dwivedi J. Himalayan bergenia a comprehensive review. Int J Pharm Sci 2012;14(2):139-41.

33. Chauhan R, Ruby K, Dwivedi J. Secondary metabolites found in Bergenia species: A compendious review. Int J Pharm Pharm Sci 2013;5(1):9-16.

34. Inoue Y, Hada T, Shiraishi A, Hirose K, Hamashima H, Kobayashi S. Biphasic effects of geranylgeraniol, teprenone, and phytol on the growth of Staphylococcus aureus. Antimicrob Agents Chemother 2005;49(5):1770-4.

35. Moonjit D, Himaja M. Phytochemical screening, GC-MS analysis and biological activities of Ipomea eriocarpa leaf extracts. Int J Pharm Pharm Sci 2014;6(4):592-4.

36. Gautam N, Mantha AK, Mittal S. Essential oils and their constituents as anticancer agents: A mechanistic view. Biomed Res Int 2014;2014:154106.

37. Park KR, Nam D, Yun HM, Lee SG, Jang HJ, Sethi G, et al. B-Caryophyllene oxide inhibits growth and induces apoptosis through the suppression of PI3K/AKT/mTOR/S6K1 pathways and ROSmediated MAPKs activation. Cancer Lett 2011;312(2):178-88.

38. Santos CC, Salvadori MS, Mota VG, Costa LM, de Almeida AA, de Oliveira GA, et al. Antinociceptive and antioxidant activities of phytol in vivo and in vitro models. Neurosci J 2013;2013:949452.

39. Adedapo AA, Adegbayibi AY, Emikpe BO. Some clinico-pathological changes associated with the aqueous extract of the leaves of Phyllanthus amarus in rats. Phytother Res 2005;19(11):971-6.

40. Kaplan LA, Szabo L, Ophenin EK. Clinical Chemistry: Interpretation and Techniques. $3^{\text {rd }}$ ed. Philadelphia, PA: Lea \& Febiger; 1988.

41. Barnett HA, O'Gara G. Diabetes and the Heart. Clinical Practice Series. Edinburgh, UK: Churchill Livingstone; 2003. p. 7-30. 